ership were also important to his success. He ended his plenary by reminding us that the final ingredient was persistence, which is achieved by being confident in who we are, in our questions, and in our perspective as primary care providers. NAPCRG members can draw inspiration and direction from these lessons as they work to improve the quality of primary health care in the United States, Canada, and around the world.

Vanessa Diaz, MD, MS

Medical University of South Carolina

From the American Academy of Family Physicians

Ann Fam Med 2007;5:91-92. 10.1370/afm.675

\section{RESEARCH DOCUMENTS SUCCESS OF AAFP'S TAR WARS PROGRAM}

The AAFP's tobacco-free education program for students, Tar Wars, works. That's the conclusion of research involving fifth-graders, their teachers and their Tar Wars presenters. "Family Physicians and Youth Tobacco-Free Education: Outcomes of the Colorado Tar Wars Program" in the November-December issue of the Journal of the American Board of Family Medicine reports on data collected in 2001-2002.

The article notes, "The Tar Wars lesson plan is effective in increasing students' understanding about the short-term consequences of tobacco use, cost of tobacco use, truth of tobacco advertising and peer norms."

According to AAFP staff members, from 10,000 to 15,000 family physicians and family medicine residents have presented the Tar Wars curriculum to about 8 million students in 50 states and 14 countries since its inception in 1988. "Outside of CME, more AAFP members have supported this program than any other Academy program," says Jeffrey Cain, MD, chief of family medicine at The Children's Hospital in Denver; assistant professor in the family medicine department at the University of Colorado Health Sciences Center, Denver; a Tar Wars cofounder; and principal investigator for the study.

"All the family physicians in Tar Wars want to know, 'Is what we're doing making any kind of a real difference among the kids?' This study answers with an emphatic 'yes.' We're making an outcomes-based difference," says Cain. "AAFP chapters can use the outcomes from this study in seeking funds for Tar Wars from foundations and other sources that require outcomesbased research."
The study used both quantitative and qualitative evaluations of Tar Wars presentations by family physicians, family medicine residents and other health educators. Researchers compared the results of 2,926 students' pretests and 2,766 students' posttests; the numbers of students taking the 2 tests varied, but the students' demographics were not significantly different, says the article. Students averaged 8.95 correct responses to 14 pretest questions, in comparison with 10.23 correct responses to the same 14 questions on the posttest. The increase seen in the number of correct posttest answers to all 14 questions compared with the number of correct pretest answers was statistically significant, says Cain.

Responses to some questions indicated "a high degree of newly acquired tobacco knowledge," says the article. For example, students could mark "true," "false" or "don't know" in response to the statement "Smoking a pack of cigarettes each day for a year would cost at least several hundred dollars." In the pretest, 67\% of students correctly answered "true," compared with $89 \%$ in the posttest.

For qualitative measures, the researchers interviewed students, teachers and presenters and held focus groups with them. According to an interview transcript, one presenter said, "When you tell them (the students) how many dollars a year cigarettes cost— $\$ 1,000$ a year for one pack a day — that's when you get the 'oohs' around the room."

"Tar Wars makes it clear that tobacco costs a lot, tobacco ads lie to you, and most kids the students' age and most adults don't smoke," said Cain. In addition, "The kids in our focus groups said that besides teaching them new things, Tar Wars covered information they had heard before but taught it in a different way that they found helpful," said Cain

Elaborating on the concept of Tar Wars as "one component" of comprehensive prevention efforts, Cain asks family physicians not only to keep presenting the Tar Wars curriculum but also to:

- promote tobacco-free policies for schools,

- encourage schools to offer tobacco-use prevention activities from kindergarten through 12 th grade,

- seek laws and regulations to make tobacco products more expensive, and

- push for statewide advertising campaigns against tobacco use.

\section{Graham Center Names Scholars' Program for Larry Green, MD}

The Academy's Robert Graham Center in Washington has named its internship program the Larry A. Green Visiting Scholars Program in honor of the person who dreamed up the internships. 
Larry Green, MD, the center's founding director, is scholar-in-residence at the center and program director of Prescription for Health in the family medicine department of the University of Colorado Health Sciences Center, Aurora.

"Among the founding purposes of the Graham Center was Larry's vision, the desire to seed the discipline of family medicine - and primary care — with young people infected with a passion for doing research, using evidence to influence policy, or both," said Robert Phillips, MD, MSPH, director of the center at a September 30th luncheon. "That vision has been realized in great part through the internship program," he added, noting that the interns (now called visiting scholars) have to their credit more than 40 projects with the center.

The Graham Center's program is "a tailored, mentored experience that permits from 4 to 6 weeks of onsite research, writing and experiential learning bounded by the guiding themes of the center and steeped in the Washington, DC, policy arena," said Phillips.
What difference does the internship make to participants who cycle through the center? Green noted 3 things:

- The interns "get a biopsy of what it's like to try to bring evidence to bear on policy"

- The interns help create a product - a paper, a one-page research document or another statement - that becomes part of the evidence base for family medicine and primary care

- The interns become part of a community of primary care researchers and policy analysts who "continue to share with one another and encourage one another."

"They are an absolute inspiration to me," Green said. "The interns are an antidote to pessimism about the future of family medicine and primary care."

Medical students, primary care residents and fellows who are interested in the Larry A. Green Visiting Scholar Program should contact Andrew Bazemore at (202) 331-3360.

AAFP News Editors

\section{CHANGE-OF-ADDRESS FORM FAMALY MEDICINE}

Please complete this form and mail to the following address or fax to Annals Circulation at 913-906-6080:

Annals of Family Medicine, Circulation Department, 11400 Tomahawk Creek Pkwy, Leawood, KS 66211-2672

Check if member of sponsoring organization: $\square$ AAFP $\square$ ABFM $\square$ STFM $\square$ ADFM $\square$ AFMRD $\square$ NAPCRG

ID number from label on your journal cover

OLD Information (Please print.)

Name

Company (if applicable)

Address (Street plus Apt or Ste)

\begin{tabular}{ll}
\hline City & State \\
\hline Country & Postal Code (9-digit ZIP for US) \\
\hline Telephone & Fax \\
\hline E-Mail & \\
\hline
\end{tabular}

NEW Information (Please print.)

\begin{tabular}{ll}
\hline Name \\
\hline Company (if applicable) \\
\hline Address (Street plus Apt or Ste) & \\
\hline City & Postal Code (9-digit ZIP for US) \\
\hline Country & Fax \\
\hline Telephone & \\
\hline E-Mail
\end{tabular}

